\title{
Petermann Glacier, North Greenland: massive calving in 2010 and the past half century
}

\author{
O. M. Johannessen ${ }^{1}$, M. Babiker ${ }^{1}$, and M. W. Miles ${ }^{2,3}$ \\ ${ }^{1}$ Mohn - Sverdrup Center at the Nansen Environmental and Remote Sensing Center, \\ Thormøhlensgate 47, 5006 Bergen, Norway \\ ${ }^{2}$ Uni Research - Bjerknes Centre for Climate Research, Allégaten 70, 5007 Bergen, Norway \\ ${ }^{3}$ Institute for Arctic and Alpine Research, University of Colorado, Boulder, CO, 80309, USA \\ Received: 10 November 2010 - Accepted: 5 January 2011 - Published: 18 January 2011 \\ Correspondence to: O. M. Johannessen (ola.johannessen@ nersc.no) \\ Published by Copernicus Publications on behalf of the European Geosciences Union.
}

\begin{abstract}
Greenland's marine-terminating glaciers drain large amounts of solid ice through calving of icebergs, as well as melting of floating glacial ice. Petermann Glacier, North Greenland, has the Northern Hemisphere's long floating ice shelf. A massive $5 \quad\left(\sim 270 \mathrm{~km}^{2}\right)$ calving event was observed from satellite sensors in August 2010 . In order to understand this in perspective, here we perform a comprehensive retrospective data analysis of Petermann Glacier calving-front variability spanning half a century. Here we establish that there have been at least four massive $\left(100^{+} \mathrm{km}^{2}\right)$ calving events over the past 50 years: (1) 1959-1961 ( 153 km²), (2) $1991\left(\sim 168 \mathrm{~km}^{2}\right),(3) 2001\left(\sim 71 \mathrm{~km}^{2}\right)$ 10 and (4) $2010\left(\sim 270 \mathrm{~km}^{2}\right)$, as well as $\sim 31 \mathrm{~km}^{2}$ calved in 2008. The terminus position in 2010 has retreated $\sim 15 \mathrm{~km}$ beyond the envelope of previous observations. Whether the massive calving in 2010 represents natural episodic variability or a response to global and/or ocean warming in the fjord remains speculative, although this event supports the contention that the ice shelf recently has become vulnerable due to extensive 15 fracturing and channelized basal melting.
\end{abstract}

\section{Introduction}

The Greenland Ice Sheet is drained by outlet glaciers that terminate on land or in the sea, and by runoff from summer melting. Mass losses from the marine-terminating or "tidewater" glaciers occur through calving of icebergs, as well as melting - primarily 20 basal - of floating glacial ice (Rignot and Kanagaratnam, 2006; Rignot and Steffen, 2008; Rignot et al., 2010; Johnson et al., 2011). Solid-ice fluxes are largely controlled by ice dynamics, such that until recently it was believed that the response time to climate forcing was on century ${ }^{+}$time scales. However, rapid changes in ice velocity, ice discharge and melt have been reported in recent years, primarily from marine25 terminating glaciers in western and southeastern Greenland, where temperate ocean- 
fjord waters play a major role in the melting (Howat et al., 2007; Holland et al., 2008; Rignot et al., 2010; Straneo et al., 2010).

Petermann Glacier $\left(81^{\circ} \mathrm{N}, 61^{\circ} \mathrm{W}\right)$ in northern Greenland has a long floating ice shelf, previously $\sim 70 \mathrm{~km}$ long and $15-20 \mathrm{~km}$ wide. The glacier velocity and terminus (i.e., 5 calving front) position have been considered to be relatively stable (Higgins, 1991; Zhou and Jezek, 2003). However, on 5 August 2010, a massive calving event (Fig. 1b) was observed from satellite sensors and reported world-wide in near real-time (e.g., Canadian Ice Service, 2010; European Space Agency, 2010; Nansen Environmental and Remote Sensing Center, 2010; National Aeronautics and Space Administration,

10 2010) The calving removed $28 \mathrm{~km}$ of the $70 \mathrm{~km}$ ice shelf, producing an ice island measuring $\sim 270 \mathrm{~km}^{2}$ (Fig. 1c-f). The 2010 calving is greater than any observed in the past 1-2 decades, the period for which extensive satellite studies have been conducted of Greenland outlet glaciers (Moon and Joughin, 2008). However, such studies provide only "snapshots" or temporally limited sequences. The long-term variability of calving

15 of Petermann Glacier is poorly known. In order to place the massive event in 2010 into perspective, it is essential to identify the frequency and magnitude of previous calving events.

Here we present a retrospective data analysis focused on Petermann Glacier calving-front variability spanning half a century, comprising the most temporallyextensive data synthesis performed for this remote glacier.

\section{Data and methodology}

The methodology is a systematic analysis of repetitive observations from Landsat and other satellites for each year over two decades (1991-2010), supplemented with sporadic satellite and aerial observations made in previous decades.

25 The source materials are comprised of: (1) digital image data from satellite sensors acquired for each year (primarily in summer) from 1991-2010, and (2) satellite and aerial observations made during the 1950 s to 1980 s. Satellite image data from several

sensor systems have been acquired and analysed (Table 1), including visible- and infrared-band Landsat Multispectral Scanner (MSS), Thematic Mapper (TM) and Enhanced Thematic Mapper Plus $\left(\mathrm{ETM}^{+}\right)$, Terra ASTER (Advanced Spaceborne Thermal Emission and Reflection Radiometer), as well as high-resolution synthetic aper5 ture radar (SAR) data from ERS-1/2 and ENVISAT satellites; SAR data are useful to delineate the calving front, regardless of cloud cover. A thorough, systematic search for additional historical Landsat, Declassified Intelligence Satellite Photographs (DISP) and other commensurate data for Petermann Glacier was conducted, with only fragmentary success. Source material prior to 1991 are primarily from results of previous 10 surveys (e.g., Dunbar, 1978; Higgins, 1991; Zhou and Jezek, 2003; Peterson, 2005).

The disparate satellite data and observations from aerial surveys were imported and consistently geo-referenced/geo-registered in the ARC-GIS geographic information system. Petermann fjord is surrounded by numerous rock outcrops that provide reliable tie-points for geo-referencing data and studying glacial motion, as well as 15 changes at the terminus, which is readily identifiable even in the presence of adjacent sea ice, as noted by Zhou and Jezek (2003).

The image data analysis is comprised of delineating the calving front and measuring changes in: (1) position relative to an arbitrary point upstream along the longitudinal axis of the glacier, and (2) area using polygon area-calculation functions applied the 20 geo-registered data.

\section{Results}

The Petermann glacier calving-front variability between 1959-2009 is summarized in Fig. $1 \mathrm{~b}$ as red lines, representing the front position in each of the 26 years with commensurate observations. The post-calving front position in 2010 has retreated $\sim \mathrm{km}$

25 beyond the envelope of previous observations. Nonetheless, closer examination reveals evidence of several major $\left(10 \mathrm{~s}\right.$ to $\left.100^{+} \mathrm{km}^{2}\right)$ calving events, as summarized in Figs. 2 and 3 and described as follows. 
Analysis of satellite images for each year 2000-2009 (Fig. 2b) confirms two major losses from calving events, in $2001\left(\sim 71 \mathrm{~km}^{2}\right)$ and $2008\left(\sim 31 \mathrm{~km}^{2}\right)$. These estimates are consistent with other recent estimates (Box and Decker, 2011).

Analysis of satellite images for each year 1991-1999 (Fig. 2c) reveals a massive 5 calving event in $1991\left(168 \mathrm{~km}^{2}\right)$ which has not previously published in the scientific literature.

Satellite data coverage for Petermann Glacier in decades before the 1990s is very sparse. Here the few available records of satellite and aerial observations of the calving-front positions from 1953 to 1978 (Dunbar, 1978; Higgins, 1991; Zhou and

10 Jezek, 2003; Peterson, 2005) are integrated and geo-registered to the same satellite image (Fig. 2d). A major retreat is evident between 1959 and 1961, as noted previously (Higgins, 1991). Here we measure the ice area calved between 1959-1962 to be $\sim 153 \mathrm{~km}^{2}$, with fragmentary evidence from the partially mapped front position in 1961 that would increase this conservative estimate by roughly $20-30 \mathrm{~km}^{2}$.

15 In order to visualize the major calving episodes through time, here we plot changes in the calving front position through the half-century ${ }^{+}$observational record (Fig. 3) Four major changes are evidenced: (1) 1959-1961, (2) 1991, (3) 2001 and (4) 2010 , although it is plausible that other major calving events occurred during the 1950s-1980s, before interannual observations were available.

$20 \quad$ Previous analyses based on limited temporal sampling missed most of these major calving events, thereby suggesting the Petermann Glacier front position to be nearly constant. First, an analysis of satellite observations from 1962, 1963 and 1992 - by chance just after the major calvings in 1959-1961 and 1991 - concluded the variability to be negligible except for "local, kilometre-scale variations" (Zhou and Jezek, 2003).

25 Second, an analysis of ice-front position changes from 1992-2007 happened to miss the two major calvings in 1991 and 2008 (Moon and Joughin, 2008). Third, a historical retrospective survey published by Higgins in July 1991 just missed the massive calving event in August-September 1991, and thus reported the 1959-1961 calving as the only major event observed.

\section{Discussion}

The $50^{+}$-year chronology put forth here establishes the occurrence of episodic major calving and suggests such behaviour is "business as usual" for Petermann Glacier. Nevertheless, the gigantic calving event of August 2010 is distinguished from previous 5 events in two ways. First, the calved ice area of $270 \mathrm{~km}^{2}$ is $60 \%$ greater than the largest previous event in 1991 of $168 \mathrm{~km}^{2}$. Second, the position of the terminus has retreated well beyond the envelope of previous observations (red lines in Fig. 1b). In contrast to the two largest known previous events observed between 1959-1961 and 1991, when the calving front was abnormally extended northwards (Fig. 2c and d), the front on 104 August 2010 (before the calving event) was well within the normal range.

The reasons for the unprecedented magnitude of the 2010 giant calving event remain speculative, as does its interpretation as: (1) a response to global warming or (2) natural episodic variability, as illustrated here. Interestingly however, a highly prescient study (Rignot and Steffen, 2008) suggested that the Petermann ice shelf has recently 15 become vulnerable to calving due to extensive fracturing, channelling and melt (basal, lateral and superficial), as observed in the field and from satellite images. In August 2010, the absence of sea ice and the presence of above-freezing ocean water in the Petermann Fjord (observed by MODIS sea-surface temperature retrievals), combined with surface melting and the aforementioned preconditioning are thus candi-

20 dates, with the calving ultimately triggered by very strong winds $\left(15 \mathrm{~m} \mathrm{~s}^{-1}\right)$ from south out of the fjord on 5 August 2010, as analysed from synoptic weather maps and retrieved from satellite SAR. 


\section{Conclusions and future research}

\subsection{Conclusions}

In this paper, we have put together and examined time series of calving front position for Petermann Glacier, 1953-2010. The half-century retrospective analysis performed here indicates that:

1. There have been at least four massive calving events over the past 50 years: (1) 1959-1961 ( 153 km²), (2) $1991\left(\sim 168 \mathrm{~km}^{2}\right)$, (3) $2001\left(\sim 71 \mathrm{~km}^{2}\right)$ and (4) 2010 $\left(\sim 270 \mathrm{~km}^{2}\right)$.

2. The magnitude of the August 2010 calving event is unprecedented in recent history, in terms of both the magnitude of ice-area lost and the retreated position of the calving front after the event $(\sim 15 \mathrm{~km}$ farther upstream than previously observed).

\subsection{Future research}

In order to further understand the reasons for - and significance of - the $2010 \mathrm{Pe}$ 15 termann calving event (and other events in many of Greenland's marine-terminating glaciers) generally needed are more in situ-data on glaciological, meteorological and oceanographic variables, combined with sequential satellite data and numerical modelling. This will provide further insight into calving rates and mass losses from Greenland outlet glaciers in the future.

20 Two specific, near-term research questions for Petermann Glacier are: (1) How can additional satellite data and other retrospective data records reveal more about its calving behaviour? and (2) Does the observational record indicate a significant increase in Petermann Glacier ice-surface velocities? The former will remain challenging unless further imagery of Petermann Glacier from the 1970s and 1980s can be located. The

latter will be addressed in a subsequent paper using long-term historical estimates and feature-tracking techniques applied to modern sequential images.

Acknowledgements. This research was supported by the Trond Mohn Foundation and the Research Council of Norway's UK/Netherlands/Norway RAPID program. The authors thank

5 Jonathan L. Bamber for early scientific suggestions; Ingrid K. Peterson for material; and KnudFrode Dagestad and Anton Korosov for technical contributions.

\section{References}

Box, J. and Decker, D. T.: Greenland marine-terminating glacier area changes, 2000-2009, Ann. Glaciol., in press, 2011.

10 Canadian Ice Service: Petermann ice island, available at: http://www.ec.gc.ca/glaces-ice/ default.asp?lang=En\&n=38952977-1, last access: 14 January 2011.

Dunbar, M.: Petermann Gletscher: possible source of a tabular iceberg off the coast of Newfoundland, J. Glaciol., 20, 595-597, 1978.

European Space Agency: Greenland glacier gives birth to giant iceberg, available at: http: //www.esa.int/esaCP/SEMYXY4OJCG_index_0.html, last access: 14 January 2011.

Higgins, A. K.: North Greenland glacier velocities and calf ice production, Polarforchung, 60, $1-23,1991$.

Holland, D. M., Thomas, R. H., DeYoung, B., Ribergaard, M. H., and Nyberth, B.: Acceleration of Jakobshavn Isbrae triggered by warm subsurface ocean waters, Nat. Geosci., 1, 659-664, 2008.

Howat, I. M., Joughin, I., and Scambos, T. A.: Rapid changes in ice discharge from Greenland outlet glaciers, Science, 315, 1559-1561, 2007.

Johnson, H. L., Münchow, A., Falkner, K. K., and Melling, H.: Ocean circulation and properties in Petermann Fjord, Greenland, J. Geophys. Res., 116, C01003, doi:10.1029/2010JC006519, 2011.

Moon, T. and Joughin, I.: Changes in ice front position on Greenland's outlet glaciers from 1992 to 2007, J. Geophys. Res., 113, F02022, doi:10.1029/2007JF000927, 2008.

Nansen Environmental and Remote Sensing Center: The Petermann ice shelf breaks up, available at: http://www.nersc.no/main/index2.php?display=moreinfo\&news_id= 322\&displayNews=1, last access: 14 January 2011. 
National Aeronautics and Space Administration: Ice island calves off Petermann Glacier, available at: http://www.nasa.gov/topics/earth/features/petermann-calve.html, last access: 14 January 2011.

Peterson, I. K.: Large tabular icebergs and ice islands off eastern Canada in 2001-2003 and

5 their probable source, Proc. Eighteenth Intl. Conf. on Port and Ocean Engineering under Arctic Conditions POAC'05, 26-30 June 2005, Potsdam, NY, 1, 143-152, 2005.

Rignot, E. and Kanagaratnam, P.: Changes in the velocity structure of the Greenland ice sheet, Science, 311, 986-990, 2006.

Rignot, E. and Steffen, K.: Channelized bottom melting and stability of floating ice shelves, Geophys. Res. Lett., 35, L02503, doi:10.1029/2007GL031765, 2008.

Rignot, E., Koppes, M., and Velicogna, I.: Rapid submarine melting of the calving faces of West Greenland glaciers, Nat. Geosci., 3, 187-191, 2010.

Straneo, F., Hamilton, G. S., Sutherland, D. A., Stearns, L. A., Davidson, F., Hammill, M. O., Stenson, G. B., and Rosing-Asvid, A.: Rapid circulation of warm subtropical waters in a major glacial fjord in East Greenland, Nat. Geosci., 3, 182-186, 2010.

Zhou, G. and Jezek, K. C.: Satellite photograph mosaics of Greenland from the 1960s era, Int. J. Remote Sens., 23, 1143-1159, 2003.

Table 1. Data sources and dates for observations of Petermann Glacier calving-front positions, 1953-2010; cf. Fig. 2b-d and Fig. 3.

\begin{tabular}{|c|c|c|c|c|c|}
\hline Year & Data source & Acquisition date & Year & Data source & Acquisition date \\
\hline 1953 & Aerial photography ${ }^{a}$ & - & 1998 & ERS-2 SAR & 1998.03.12 \\
\hline 1959 & Aerial photography ${ }^{a}$ & - & 1999 & Landsat $7 \mathrm{ETM}^{+}$ & 1999.07.07 \\
\hline 1962 & DISP $^{\mathrm{b}}$ & 1962.05 & 2000 & Landsat $7 \mathrm{ETM}^{+}$ & 2000.08 .19 \\
\hline 1963 & DISP $^{\mathrm{b}}$ & 1963.10 & 2001 & Terra ASTER & 2001.07 .17 \\
\hline 1975 & Aerial SLAR ${ }^{\mathrm{C}}$ & 1975.03 .13 & 2002 & Terra ASTER & 2002.07 .20 \\
\hline 1978 & Aerial photography ${ }^{c}$ & - & 2003 & Terra ASTER & 2003.07 .23 \\
\hline 1991 & ERS-1 SAR & 1991.08 .19 & 2004 & Landsat $7 \mathrm{ETM}^{+}$ & 2004.08 .06 \\
\hline 1992 & ERS-1 SAR & 1992.09 .16 & 2005 & Landsat $7 \mathrm{ETM}^{+}$ & 2005.08 .29 \\
\hline 1993 & ERS-1 SAR & 1993.03 .07 & 2006 & Landsat $7 \mathrm{ETM}^{+}$ & 2006.07 .02 \\
\hline 1994 & ERS-1 SAR & 1994.05 .27 & 2007 & Landsat $7 \mathrm{ETM}^{+}$ & 2007.07 .13 \\
\hline 1995 & ERS-1 SAR & 1995.09 .27 & 2008 & Landsat $7 \mathrm{ETM}^{+}$ & 2008.07 .31 \\
\hline 1996 & ERS-2 SAR & 1996.03 .01 & 2009 & Landsat $7 \mathrm{ETM}^{+}$ & 2009.07 .30 \\
\hline 1997 & ERS-2 SAR & 1997.03 .21 & 2010 & ENVISAT ASAR & 2010.08 .04 \\
\hline
\end{tabular}

ASAR - Advanced Synthetic Aperture Radar

DISP - Declassified Intelligence Satellite Photographs

$\mathrm{ETM}^{+}$- Enhanced Thematic Mapper Plus

SAR - Synthetic Aperture Radar

SLAR - Side-Looking Airborne Radar

${ }^{a}$ Digitized from Peterson (2005), after Higgins (1991).

${ }^{b}$ Digitized from Peterson (2005), after Zhou and Jezek (2003).

cDigitized from Peterson (2005), after Dunbar (1978). 

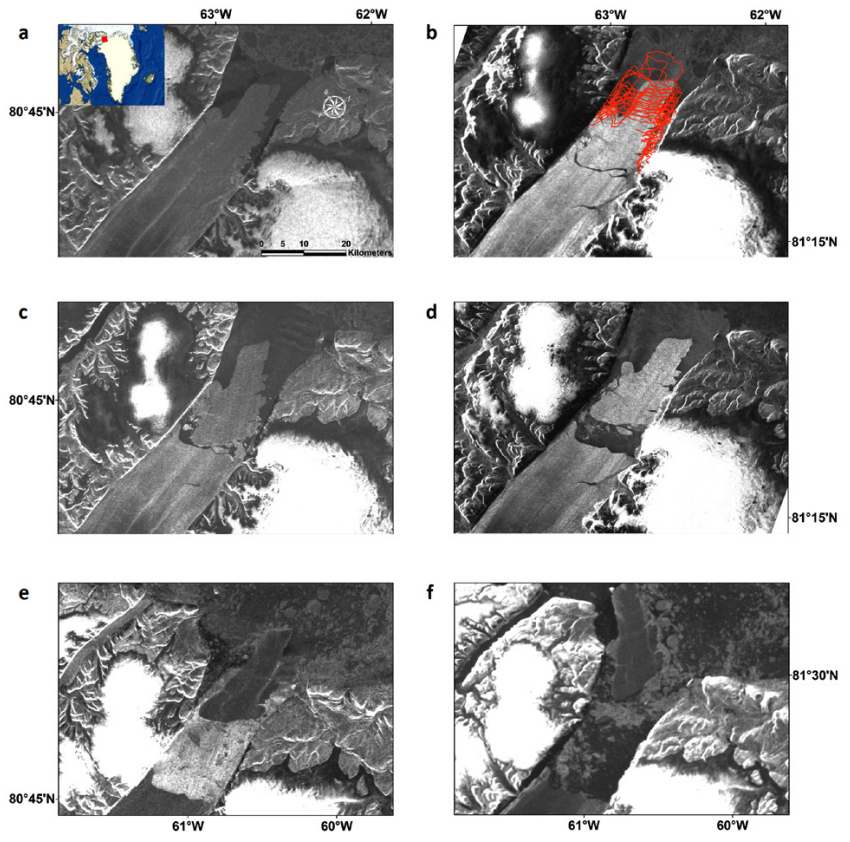

Fig. 1. Time sequence of the massive calving event of Petermann Glacier in 2010. ENVISAT Advanced Synthetic Aperture Radar (ASAR) images, August-September 2010. (a) ENVISAT ASAR image, 3 August, (b) ENVISAT ASAR image, 4 August, (c) ENVISAT ASAR image, 5 August, (d) ENVISAT ASAR image, 7 August, (e) ENVISAT ASAR image, 26 August, (f) ENVISAT ASAR image, 4 September. The calving event started on 4 August 2010 with a 300-900 m crack (dark feature in b across the ice shelf, $28 \mathrm{~km}$ from terminus). The overlain red lines in $b$ indicate the calving-front positions mapped from 1959-2009 - see Fig. 2 for details. ENVISAT images are copyright ESA.
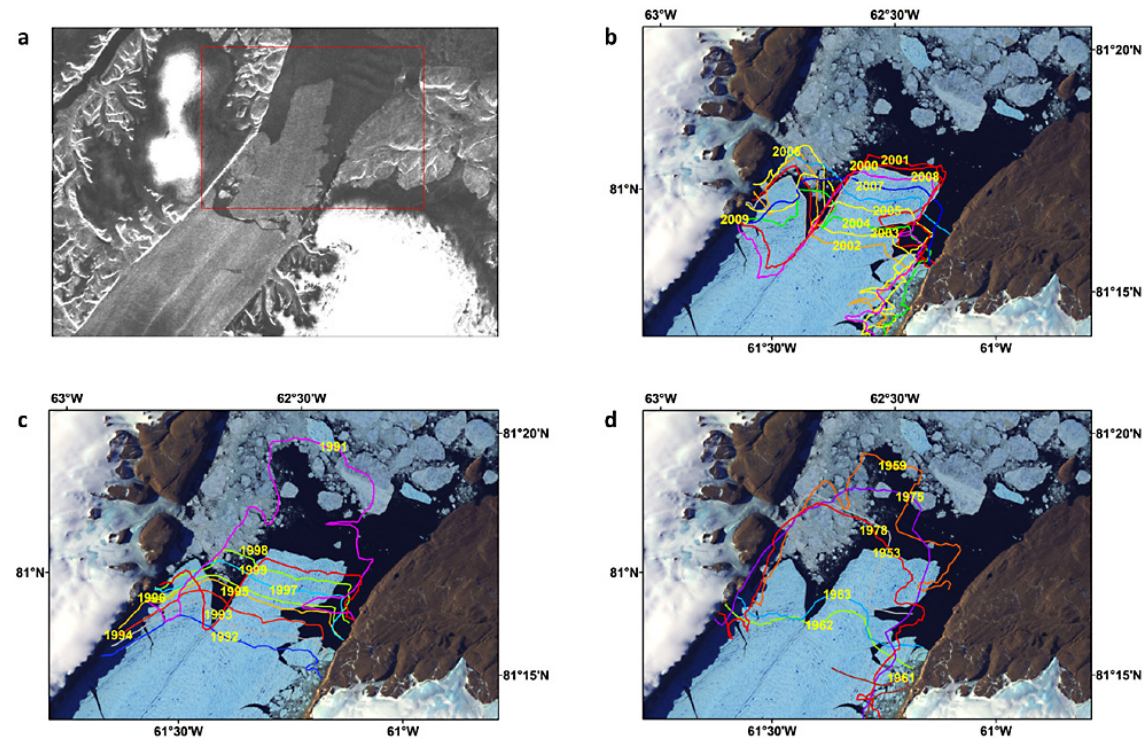

Fig. 2. Petermann Glacier calving-front variability, 1959-2009. (a) ENVISAT advanced synthetic aperture radar (ASAR) image of the massive ice island calved on 5 August 2010 (same as Fig. 1c); red frame is the area shown in (b-d), (b) Interannual variability (coloured lines) of the calving front, 2001-2009, derived from satellite images, (c) Interannual variability (coloured lines) of the calving front, 1991-2000, derived from satellite images, (d) Calving-front variability (coloured lines) pre-1990s, derived from observations from satellite imagery and aerial photography. Note that the time intervals in (d) are irregular and greater than in (b) and (c), and note that the 1961 position (brown line in (d)) is only partially mapped. The delineations in (b-d) are superposed on the same Landsat Enhanced Thematic Mapper Plus $\left(\mathrm{ETM}^{+}\right)$image from 19 August 2000. 


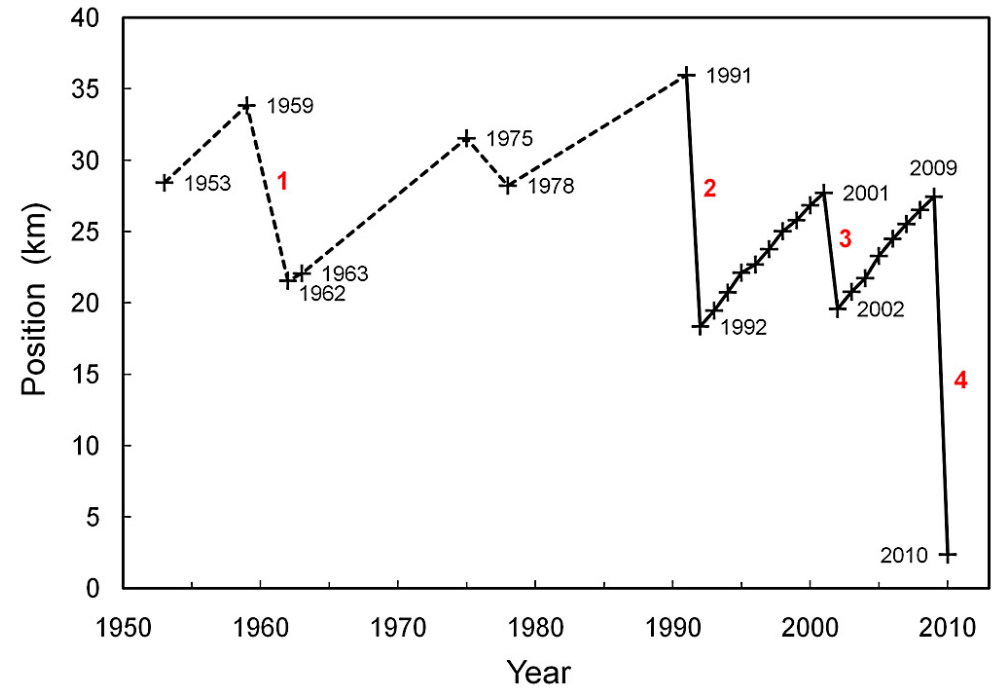

Fig. 3. Petermann Glacier calving-front positions (+ symbol) observed between 1953 and 2010 , cf. Fig. $2 b-d$. Positions are indicated relative to an arbitrary reference point along the longitudinal axis of the floating ice tongue. Solid line: Interannual variability of the calving-front position, 1991-2010, derived from satellite images, Dashed line: Variability of the calving front position, 1953-1991, derived from sporadic satellite and aerial observations. Red numbers denote the four largest changes in the record: (1) 1959-1961, (2) August-September 1991, (3) September 2001 and (4) August 2010. Data sources are provided in Table 1. 